\title{
Research on Entrepreneurship - Forms of Entrepreneurship
}

\begin{abstract}
Julita E. Wasilczuk*
The aim of this article is to present suggestions for future directions of research on entrepreneurship, with particular emphasis on different forms of entrepreneurship. The suggestions are preceded by a brief review of research on entrepreneurship. The article is theoretical in nature and does not present any own research, although its content is based on multiple years of experience in studying this phenomenon. The forms of entrepreneurship are discussed in terms of relationship with business, methods of organization, ownership of capital, effect of entrepreneurial activities, phases of entrepreneurial activities and persons conducting business. The need to consider forms of entrepreneurship during research in such topic areas as governance methods and strategy selection, entrepreneurial motivation, innovations or the effects of entrepreneurial activity was pointed out.
\end{abstract}

Keywords: entrepreneurship, research on entrepreneurship.

Submitted: 14.09.2016 | Accepted: 21.10.2016

\section{Badanie przedsiębiorczości a jej rodzaje}

Celem artykułu jest zaprezentowanie możliwych kierunków badań nad przedsiębiorczościa, ze szczególnym uwzględnieniem różnych jej rodzajów. Sugestie te zostaty poprzedzone krótkim przegladem badań nad tym tematem. Artykut ma charakter teoretycznych, aczkolwiek zawarte w nim tezy sa wynikiem wieloletnich doświadczeń. Rodzaje przedsiębiorczości przedstawiono, opierając się na zwiazku z: działalnościa gospodarcza, metodami organizacji, wtasnościa kapitału, efektem działalności przedsiębiorczej, faza tej dziatalności oraz osoba samego przedsiębiorcy. Potrzeba uwzględniania różnych rodzajów przedsiębiorczości jest szczególnie istotna $w$ przypadku takich obszarów badań, jak: metody zarządzania przedsiębiorstwem $i$ wybór strategii, motywacje przedsiębiorcze, innowacje oraz efekty działalności przedsiębiorczej.

Słowa kluczowe: przedsiębiorczość, badania nad przedsiębiorczością.

Nadesłany: 14.09.2016 | Zaakceptowany do druku: 21.10.2016

JEL: L26

Julita E. Wasilczuk, Associate Professor, PhD (habilitated) - Gdańsk University of Technology.

Mailing address: Gdańsk University of Technology; ul. Narutowicza 11/12; 80-233 Gdańsk; e-mail: Julita. Wasilczuk@zie.pg.gda.pl. 


\section{Introduction}

Entrepreneurship can be manifested in varied activities, from conducting business as a sole trader (self-employment in the narrow sense, understood as lack of staff) to running several businesses at the same time. It can be implemented in the area of business, but also in the domain of politics. The entity pursuing entrepreneurial activities may be a woman, an elderly person or a twenty-something youngster. The result of entrepreneurial activities may be an increase in the gross domestic product, but also its decline. Enterprising conduct may be shown both by individuals running their own companies and by people responsible for separate tasks within a larger organization. Each of these manifestations or forms of entrepreneurship exists in the modern world and is increasingly being taken into account when conducting research on entrepreneurship. An example can be social entrepreneurship (see: Seymour, 2012), women's (see: Hughes, Jennings, Brush, Carter and Welter, 2012) or minorities' entrepreneurship (see: Wood, Davidson and Fielden, 2012), family entrepreneurship (see: De Massi, Sharma, Chua and Chrisma, 2012), franchising (see: Buzza, 2016) or intrapreneurship. Each of these forms of entrepreneurship, as well as entrepreneurship itself, has been defined many times. This article does not contain deliberations on issues related to definitions and is limited only to general terms relating to different forms of entrepreneurship (e.g. family entrepreneurship or social/political entrepreneurship, etc.).

\section{Entrepreneurship as an Object of Study - History ...}

Modern research on entrepreneurship has been conducted for several decades now, and almost every article about it begins with pessimistic statements about the lack of a universally accepted definition of entrepreneurship or the lack of a clear explanation of the phenomenon of human entrepreneurial activity. The research in this area is conducted by numerous adepts of all branches of science around the world - economists, sociologists, psychologists and even anthropologists are trying to apply research methods specific to their fields in order to answer the question of who, why and how becomes an entrepreneur and benefits from this.
Even though the entrepreneurial activity is one of the oldest, the research on it began relatively recently - hence the lack of well-shaped research methods (Landstrom, 2005; Bygrave, 2007; Davidsson, 2009) or paradigms (Kurczewska, 2013, p. 28).

Gartner calculated in 1988 that the number of definitions of an entrepreneur exceeded 90 (1988), and until now has probably doubled. The reason for this is, inter alia, that entrepreneurship is analysed from the perspective of different disciplines (economics, management, sociology, psychology), although it is assigned to management science (Ries, 2010; Cyfert, Dyduch, Latusek-Jurczak, Niemczyk and Sopińska, 2014).

The first research studies on entrepreneurship began in the 1940s, with the advent of the magazine published by the Harvard Business School: Explorations in Entrepreneurial History (Jones and Wadhwani, 2006). However, the word "entrepreneur" is not a modern invention, as it was mentioned already in the dictionary of the French language from 1437, where it was given three meanings - among them the one most relevant for today's understanding of this concept: "A person who is active or intends to achieve something" (Landstrom, 2005). One of the first descriptions of entrepreneurial activity appeared in 1755 when Cantillon (Irish baker living in Paris) published a paper which included a remark about the discrepancy between supply and demand which created the possibility of earning from reselling cheaply bought goods (Landstrom, 2005). Cantillon clearly distinguished between the traits of a capitalist and the characteristics of entrepreneurs. His merit was also cementing the links between notions of entrepreneurial activity and risk for the purposes of further research. He is also considered the "father" of the concept of entrepreneurship (Filion, 1998), although some attribute it to Mill (Brockhouse and Horwitz, 1986). The understanding of an entrepreneur as a risk-taker appeared in the legal and economic literature of the 17th and 18th centuries (Landstrom, 2005).

In the English language, common nowadays, the concept of the entrepreneur was introduced later than in French, and its definition can be found in a dictionary of English from 18th century, which defines an entrepreneur as an adventurer, a seeker 
of dangers and the one who entrusts his fate to chance (Landstrom, 2005). In the mid-eighteenth century, the concept started to be identified with the notion of a businessman or an individual organizing a large project - and it was this sense that Adam Smith used it in his memorable work, An Inquiry into the Nature and Causes of the Wealth of Nations. With time, this concept has begun to be replaced with the term "capitalist", as capital has become the most important factor of economic development. And so, with the advent of classical economics, the entrepreneur - both in the conceptual framework and in reality - has been pushed into the background, giving way to the capitalist for many years. The concept was restored by Say (van Praag, 1999), who changed its perception and presented the entrepreneur as a coordinator, describing their functions and role in the economy. Say also wrote about the topic of risk.

The 19th century brought a change of perspective from macro- to microeconomics, which generally favoured defining and describing entrepreneurship. Marshall, however, according to the English tradition, stopped at perceiving the entrepreneur as a "multifunctional" capitalist (Landstrom, 2005). In his later work, he also emphasized the entrepreneur's role as an educator of initiatives, being the main source of progress at the same time. The interest in entrepreneurship was not limited only to the British and French researchers, as the Germans also joined the stream of research. A prime example is von Thünen, who distinguished an entrepreneur from a capitalist based on obtained return of expenses, which in the case of entrepreneurs stems also from the risk involved (Kirby, 2003, p. 12). Another example of a researcher was Mangoldt, who proposed to treat the entrepreneur as a separate factor of production, while continuing to advance von Thünen's postulate concerning the remuneration of the entrepreneur for the risk taken (Hutchinson, 1966). On the other side of the ocean, in the United States, the discussion on entrepreneurship began in the 19th century, and its most famous representative is Knight, who defines entrepreneurship as "real uncertainty" involving not only an unknown future but also the inability to know it (Landstrom, 2005).
Undoubtedly one of the most distinguished researchers in the creation of the theory of entrepreneurship is Schumpeter, who is primarily associated with the study of innovation. After years of marginalization in the literature, he brought the entrepreneur back to the level of one of the most important entities in the theory of economics.

To sum up, in the past, the entrepreneur played different roles in the theory of economics and was defined in different ways. Hebert's and Link's collection of past descriptions of entrepreneur roles shows that each of the theorists pointed to more than one role, while the roles assigned by various authors overlap (Hebert and Link, 1989, p. 152).

\section{Entrepreneurship in Contemporary Research}

The above-mentioned historical achievements of economists were primarily based on describing the role of the entrepreneur in economics, while failing to take into account what happens inside the enterprise. They also failed to take into account the role of the entrepreneur as a person by omitting the factors affecting their subjective and often irrational decisions. One can even get the impression that economists negated entrepreneurship as a phenomenon worthy of interest (see: Baumol, 1968; Johansson, 2004; Bianchi and Henrekson, 2005). It sometimes appears as an element important for the economic development (see: Carree and Thurik, 2003).

The lack of entrepreneurship in economics has been proven quite eloquently by Johansson (2004), who analysed the textbooks used in doctoral studies of economics in Sweden. He assumed that the indexes of textbooks contain all the important concepts students should assimilate. Among 19 economics textbooks recommended for doctoral students, he found references to entrepreneurship in two, whereas references to institutions that shape entrepreneurship could be found in five books. It follows that economists treat the company as worthy of interest but fail to deal with entrepreneurs as persons, who frequently act with limited rationality and make impulsive decisions, often unsupported by thorough economic knowledge. As noted by Baumol, "the theoretical company has no 
entrepreneur" (Baumol, 1968). Gruszecki also observes that a company without an entrepreneur is an empty shell (Gruszecki, 2002, p. 160).

Pushing the discussion on entrepreneurship to the margin of economics is partially the "fault" of entrepreneurship itself, which defies the framework of mathematical economics as a science. It is as result of the fact that, as Barreto observes, entrepreneurship cannot be packed into a mechanistic, deterministic model (1989, p. 141). The obstacle here is the "irrational entrepreneur", who is not always seeking to maximize profit sometimes they are more interested in their personal goals (family maintenance while being able to choose between leisure and work, following one's passions or social mission, etc.). Meanwhile, the science of economics does not have the capability to measure the subtle aspects related to the psyche of the entrepreneur, their lack of rationalism or motivating incentives, which are not always purely economic (see above) and may result in situations when economically non-viable companies are maintained for many years. Another factor that impedes putting the phenomenon of entrepreneurship into the framework of the economic theory is high diversification of types of businesses in the market. This leads to the impossibility of creating a general model of entrepreneur and the effects of their activity, as well to the lack of a uniform definition of entrepreneurship and entrepreneurs, as discussed below.

These limitations were noticed by Penrose, who suggested expanding research on entrepreneurship with research on the behaviour of entrepreneurs based on other sciences, such as psychology (Penrose, 1959). This postulate is nowadays often used, as psychology focuses on the individual and its perception of surroundings as well as the implications of such perception for its behaviour and choices. Undoubtedly, the pioneer of research on the psychological aspects of entrepreneurship is David McClelland, who was the first to conduct empirical studies based on behavioural theories (Landstrom, 2005, p. 40). Particularly helpful in understanding the functioning of entrepreneurs and their decisionmaking is the work of McClelland, related to motivation. McClelland focused in his work primarily on the need for achievement $(n A C H)$, however he also took into account the risk appetite.

In the contemporary research on entrepreneurship, much attention is devoted to entrepreneurial motives, perceived through the prism of opportunity and necessity. Such approach is used in the Global Entrepreneurship Monitor studies (2014). One can also meet such terms as pull (positive) or push (negative) factors (Storey, 1994). Each of the two groups is assigned individual motives; however, it is known that entrepreneurs are usually guided by a set of motives, in which those from one of the two groups are predominant. The motives from the opportunities group are of a more stimulating nature than those from the necessity group. An entrepreneur forced to establish a company by dissatisfaction with previous work, difficulties in finding suitable employment, unemployment, or the need to maintain a family (Boeker, 1989) is less likely to succeed in their business and vice versa, the positive motives prevailing in the process of founding a company contribute to its success to a greater extent (Cooper and Gimeno-Gascón, 1992; Wasilczuk, 2005).

Another area of research of entrepreneurship using psychological aspects are intentions. The definition of intention says that it is a state of mind that directs a person's behaviour as well as attention towards a specific way of conduct (Krueger, Reilly and Carsrud, 2000). Therefore, the immanent part of it is the intended action. Intentions are stimulated by motivations. Both the intention and motivation are crucial in many fields related to entrepreneurship and - as noted by Krueger (2003, p. 115) - studying entrepreneurship without looking at why some people establish companies and others do not would not make sense. In the literature on entrepreneurship, and in particular nascent entrepreneurship, there are references to two models of intentions: Theory of Planned Behaviour of Ajzen and Fishbein (Ajzen and Fishbein, 1975) and the Shapero's Model of the Entrepreneurial Event (Shapero and Sokol, 1982).

However, for a long time one of the main areas of psychological research were the personality traits that the ideal entrepreneur should possess (Brockhouse and Horwitz, 1986; Chell, 1996). Today, 
it is already known that an ideal set of personal characteristics of an entrepreneur does not exist - however, certain traits favour entrepreneurship, like: willingness to take balanced risk, Internal Locus of Control, perseverance, determination, innovativeness, need for achievement, self-efficacy (McClelland, 1965; Rauch and Frese, 2000; Chatterjee and Das, 2015; Staniewski, 2016). However, one cannot talk about any hierarchy of personal traits. All of these are important in entrepreneurship, although their significance varies at different stages of business development. Nevertheless, the attempts at identifying the traits conducive to entrepreneurship are still in progress (Staniewski, 2016). This approach is the subject of frequent criticism, initiated by Gartner with an article with the revealing title: "Who is an Entrepreneur?" Is the Wrong Question (Gartner, 1988). Gartner called for focusing on what the entrepreneur is doing (behavioural approach) and not who they are. The critical comments on the research on personality traits in research studies, mainly from the eighties, (Chell, 1985; Gartner, 1988) can be reduced to a few main points (Wasilczuk, 2005):

- ambiguity of personality traits, which are usually studied individually;

- impact of various personality traits that may differently affect individual entrepreneurial "events";

- reliance on ongoing research of questionable quality ${ }^{1}$;

- reliance on research conducted on different groups of entrepreneurs (this issue is described later in this article);

- attachment to the "traditional" set of personality traits - the frequently conducted research focuses on the so-called Big Five.

- omitting other factors affecting entrepreneurial activity, aside from the personality traits, e.g. the context, institutions, environment, etc.

\section{Quo Vadis, Research on Entrepreneurship?}

Today, every piece of research requires a precise definition of the notion of an entrepreneur, as there is no single universal definition of the term. This leads to the proliferation of definitions and reaching consensus on this topic seems unlikely ${ }^{2}$.
One of the attempts to introduce a uniform definition is the Global Entrepreneurship Monitor research (Global Entrepreneurship Monitor Association, 2014), as its temporal and territorial coverage may allow for reproducing the agreed definition in other studies. However, the definition used in these studies is very broad and refers both to people who have not yet established a company but are already taking steps to do so and to those who are already running businesses (GEM's definition of entrepreneurship: "Any attempt at new business or new venture creation, such as selfemployment, a new business organization, or the expansion of an existing business, by an individual, a team of individuals, or an established business"). The first group, called nascent entrepreneurship, is rarely taken into consideration in official national statistics.

The diversity of research topics, but also of research methodology, provokes researchers to create overviews of current research achievements (see e.g.: Audretsch, 2012; Davidsson, 2005; Davidsson, 2008; Gartner, 2001; Kurczewska 2013, p. 17-69; Landstrom and Lohrke, 2010, Zahra and Dess, 2001). Worth quoting here, but rather pessimistic, is the opinion of Kilby from 1971, who noted that entrepreneurship is like a Heffalump, which is a mythical creature described by Milne in the classic children's novel Winnie the Pooh. “...a rather large and important animal. He has been hunted by many individuals using various trapping devices, but no one so far has succeeded in capturing him. All who claim to have caught sight of him report that he is enormous, but disagree on his particulars" (Kilby, 1971). This "Heffalump" is still haunting researchers.

In view of the dilemmas related to conducting research, there appears an increasingly stronger pressure to isolate entrepreneurship as a separate scientific discipline (Corbetta, Huse and Ravasi, 2005, pp. 4-5; Moczydłowska, 2013). This is not the only direction indicated in the literature in which, according to the researchers, entrepreneurship will be aimed (Corbetta, Huse and Ravasi, 2005, pp. 4-5). A denial of this trend is the synthetic trend, oriented towards a public policy and uniting representatives of many disciplines, although derived from economics. The current of strategic integration postulates 
the perception of entrepreneurship through the prism of the strategy and its inclusion into the study of management. In contrast, the specialist current integrates multiple threads associated with the various manifestations of entrepreneurship (family entrepreneurship, technology entrepreneurship, internationalization or female entrepreneurship). In the literature, there are also calls for more targeted research on entrepreneurship, closer to contextual research (Welter, 2001), as the factors affecting the economic activity cannot be analysed and compared in isolation from a historical background, cultural conditions, etc.

The review of the literature in leading journals dealing with entrepreneurship ${ }^{3}$ indicates that the subjects of research related directly or indirectly to entrepreneurship are diverse and include:

- the theoretical basis (research, defining);
- the process of setting up (intentions, motivations, financing, barriers, etc.);

- strategies and innovations (implementation, management, management efficiency, etc.);

- the development of entrepreneurship (paths, factors, strategies, barriers, etc.);

- entrepreneurship education (methodology, the impact on entrepreneurial intentions);

- the role in the economy and the support policy (impact on macroeconomic parameters of the economy, barriers to development, methods and results of support);

- specific forms of entrepreneurial activities (e.g. social, family, etc.).

The research on the above-mentioned subjects is sometimes targeted towards a specific form of entrepreneurship, which allows for adjusting research tools to the most common problems within a particular form of entrepreneurship. The analyses

Table 1. Types of entrepreneurship

\begin{tabular}{|c|c|}
\hline Criterion of division & Types of entrepreneurship \\
\hline Relationship with business & $\begin{array}{l}\text { Economic entrepreneurship } \\
\text { Intellectual/Academic entrepreneurship } \\
\text { Social entrepreneurship } \\
\text { Political entrepreneurship }\end{array}$ \\
\hline Method of organization & $\begin{array}{l}\text { Self-employment/Solo entrepreneurship } \\
\text { Hybrid entrepreneurship } \\
\text { Entrepreneurship in franchising } \\
\text { Multi-/Serial entrepreneurship } \\
\text { Family entrepreneurship }\end{array}$ \\
\hline Ownership of capital & $\begin{array}{l}\text { „Traditional” entrepreneurship } \\
\text { „Intrapreneurship” } \\
\text { Corporate entrepreneurship }\end{array}$ \\
\hline Result of entrepreneurial activities & $\begin{array}{l}\text { Productive entrepreneurship } \\
\text { Unproductive entrepreneurship } \\
\text { Destructive entrepreneurship }\end{array}$ \\
\hline Phase of entrepreneurial activities & $\begin{array}{l}\text { Pre-entrepreneurship } \\
\text { Young entrepreneurship } \\
\text { Mature/Managerial entrepreneurship }\end{array}$ \\
\hline Business operator & $\begin{array}{l}\text { Women's entrepreneurship } \\
\text { Minorities' entrepreneurship } \\
\text { Seniors' entrepreneurship }\end{array}$ \\
\hline
\end{tabular}

Source: own work 
concerning the preparation of family businesses for succession are an example of such orientation. Another example is the study of motivation of enterprising students or barriers that arise in the activities of women, ethnic minorities or the elderly. This growing awareness of the diversity of entrepreneurship forms is reflected in classifications/typologies of entrepreneurship emerging in the literature of the subject (see e.g.: Kurczewska, 2013, p. 38; Piecuch, 2014). The division criteria presented in Table 1 are another proposal to systematize forms of entrepreneurship, taking into account the earlier reports from the literature. Due to the nature of the individual criteria, the presented forms of entrepreneurship are not mutually exclusive, which means that there is a possibility to create sub-categories, linking e.g. the criterion of the organization method and the person performing the entrepreneurial activity.

\section{The Relationship with Business Criterion}

The most common understanding of entrepreneurship refers to the desire to achieve profit as the main engine of entrepreneurial activities performed through paid provision of goods or services. It is not entirely clear, however, at which point the typical so-called conventional business ends and social, institutional, cultural or intellectual entrepreneurship begins. While in the conventional entrepreneurship main objectives are economic in nature, in the intellectual, social or cultural types of entrepreneurship the goals are broader and may include the promotion of the values/knowledge, social change (improving welfare) or the promotion of cultural values. This difference, however, depends on what definition we accept as binding, both in the case of social entrepreneurship and in all the other cases.

The basis of intellectual entrepreneurship is enterprise and intellect, and in the most general way it can be defined as creating the basis for material wealth based on intangible knowledge (Kwiatkowski, 2000). Intellectual entrepreneurship is associated with new concepts, such as academic entrepreneurship, spin-offs and innovations. The central element of intellectual entrepreneurship is the intangible value in the form of knowledge, idea, invention or innovation that can be patented or not. In many cases, achieving financial benefits in the case of intellectual entrepreneurship plays a rather supporting role. The essence is the "product" itself which, due to being placed in a business context, is introduced into use and brings the owner income in addition to satisfaction.

The aim of social entrepreneurship is social change, and its measure is the resulting social capital, while, as in the case of intellectual entrepreneurship, reaping financial benefits is of secondary importance. The area of interest in the case of social entrepreneurship covers activities that are entrepreneurial in nature but focused on social innovation and the promotion of social values, regardless of whether this applies to a business company, pursuing such goals in addition to commercial activity, or to a typical social enterprise oriented mainly towards the implementation of such actions (this is a great simplification of the concept of social entrepreneurship, but it is not the main subject of this article).

A relatively new area of research, to which little space in the literature is devoted, is political entrepreneurship, which applies to people working in the public sphere in an entrepreneurial/innovative way, using their entrepreneurial talents to introduce changes by creating new institutions or transforming the existing ones (Kostera and Śliwa, 2012, p. 238).

Cultural entrepreneurship is defined by Aageson as introducing cultural changes through the organization of limited cultural, financial, social and human resources (Aageson 2008). It is largely based on emotion and not on the conventional activity.

\section{The Criterion of Organization Method}

According to the way of organization, such forms of entrepreneurship as selfemployment, hybrid entrepreneurship, franchising, serial entrepreneurship, and family entrepreneurship can be distinguished. The method of enterprise organization determines the manner of its management to a large extent. In an enterprise that does not employ any employees, there is no need for human resources management. Self-employment understood as lack of employees may be 
a result of starting a business by a potential employer due to a dire necessity or may occur where an entrepreneur has just started an activity and employment will be a result of company development. It is also a common symptom of the activity of entrepreneurs from creative industries, who are self-employed and do not need any employees. In a family business, the area of human resources management should be treated with great sensitivity, both in relation to the involved family members and to the employees not related to the owner family. The number of interactions and possible conflicts increases due to the presence of a specific group of people involved, that is the owning family. There are also numerous additional areas requiring the involvement of entrepreneurial talent, such as succession and long-term planning. In the case of the operation in a network, e.g. a franchise, the entrepreneur does not have to deal with promotion and is also relieved of the necessity to innovate. To a large extent, their activities constitute "limited" entrepreneurship, involving the use of a business model created by the parent company. On the other hand, a hybrid activity, consisting in running a company apart from full-time employment, carries less psychological stress associated with the threat of bankruptcy, as the entrepreneur has an alternative source of income. Nevertheless, balancing personal life with work does not allow for total dedication to the company. Hybrid entrepreneurship occurs most often in the case of selfemployment - it may also be temporary and result from a desire to test oneself in business and eventually convert to fulltime entrepreneurship in the future (Folta, Delmar and Wennberg, 2010). Running a company while being a full-time employee may result from the inadequacy of income generated by the company or from a desire to fulfil one's passions, which cannot be achieved in the everyday work. According to some studies, combining a regular job with conducting business is frequent in certain countries, reaching almost $50 \%$ of all companies in the case of start-ups (Burke, FitzRoy and Nolam, 2008; Petrova, 2011).

The necessity of sharing time, entrepreneurial talents and financial resources between two or more businesses is also characteristic for portfolio entrepreneurship ${ }^{4}$, which means running several com- panies at the same time (Westhead and Wright, 1998). It is a nuisance, but it can also be used to support the enterprises which are temporarily in need. Also, the experience gained over the course of running more than one company cannot be overestimated (Rosa and Scott, 1999; Rerup, 2005).

\section{The Phase of Entrepreneurial Activities}

Entrepreneurial activities require changing competences of the entrepreneur themselves, as clearly pointed out by Churchill and Lewis, who link this fact with phases of company development (Churchill and Lewis 1983). In the initial stages, when the idea germinates, best solutions are sought and first steps to start a business are taken (nascent entrepreneurship), the main problem is related to the financial resources necessary to start a business, and the future entrepreneur shows full commitment to the activity. A young company, already operating in the market, is another challenge for the "young" entrepreneur, who usually has numerous ideas. During this period, they learn about their limitations, gain new skills and prove that the initial success related to the establishment of an enterprise was not an accident. Mature entrepreneurship is the phase of the activity of an entrepreneur who has been running their company for a long time - the enterprise begins to live its own life and does not require such involvement of the entrepreneur as in the previous phases. During this period, the entrepreneur begins to act in a routine way - all the ideas have been put into practice and the prose of everyday operation of the company means that they become more of a manager than of an entrepreneur.

It is difficult to determine the time frame of particular phases, although the largest worldwide study on entrepreneurship, Global Entrepreneurship Monitor, revealed that the border between young and mature entrepreneurship is 3.5 years of activity (Donna, Singer and Herringron, 2016). Each phase of entrepreneurship requires a different approach and different intensity of entrepreneurial activities. Along with the transition to the next phase, the entrepreneur must strive to maintain the entrepreneurial spirit and prevent being forced into the framework of routine company management. 


\section{Business Operator}

Entrepreneurs vary depending on gender, age or nationality. The popular areas of research in this case are women's entrepreneurship (see e.g.: Neergaard, Shaw and Carter 2005; Jennings and Brush, 2013) and entrepreneurship of minorities (Bates, 2011). With the ageing of population, there appears a new stream of research, focusing on the entrepreneurship of senior citizens (Halabisky, 2012; Wasilczuk, 2014). In the English-language literature, the most common term for the entrepreneurs of older age is grey or silver entrepreneur; however, also the terms mature and senior entrepreneur are used. As an expression of appreciation of the retirees' willingness to set up businesses, also the term second career entrepreneur was introduced. The research on the activity of older entrepreneurs indicates their lower willingness to develop their businesses and preferences related to stability company growth is less likely to be their main objective (Richert-Kaźmierska and Wasilczuk, 2014). Much attention in the research is devoted to young entrepreneurs, and the ease of conducting research on groups of students means they are often the objects of analysis on the entrepreneurial potential of young people and their tendency to establish companies (Zięba, 2016).

\section{Ownership of Capital}

The division of entrepreneurship according to the ownership of capital covers the so-called traditional entrepreneurship, involving starting an enterprise on the basis of equity or borrowed capital, as well as intrapreneurship. The latter term was introduced by Pinchot, who is also the author of the 10 commandments of intrapreneur (Pinchot, 1984, p. 22). The intrapreneur uses their entrepreneurial talents to make something new, even though it is not covered by their job description - such person is characterized by thinking outside the box.

\section{The Result of Entrepreneurial Activities Criterion}

One of the elements analysed within the framework of research on entrepreneurship are the barriers to the functioning of businesses resulting from institutional conditions. Institutional economics as a research stream includes Baumol's division of entrepreneurship according to the effects of entrepreneurial activity (1990). The author showed no links between the gross domestic product and the number of entrepreneurs in different countries, explaining it with an inefficient use of entrepreneurial talent and at the same time introducing three types/effects of entrepreneurial activity: productive, unproductive and destructive (in later works called also predatory) (Henrekson, 2007). This division was based on a set of actions that require entrepreneurial talent and do not contribute to the increase in total production - in some cases they can even decrease it. The inefficiencies from the point of view of the overall economy are not always associated with the unproductivity of the entrepreneur - their actions, which "devastate" the production of other companies, can actually be beneficial for the otherwise destructive entrepreneur.

One may wonder whether it makes sense to multiply forms of entrepreneurship and their definitions. It seems, however, that Davidsson and Wiklund's call for distinguishing between SMEs and entrepreneurship (Davidsson and Wiklund, 2001 ) is still valid. This appeal is a result of a large diversity of entrepreneurial forms, which do not always show up in the scale of a single company (serial entrepreneurship) or even do not have much in common with traditional companies (political or social entrepreneurship). Failing to differentiate enterprises according to their organization or the person of the entrepreneur does not allow for the full use of the conducted research.

\section{Conclusion}

The research on entrepreneurship has been underway for many years. In recent years, in parallel to the study of entrepreneurship, the analyses of methods of its research are conducted. The problem is related not only to the lack of a uniform definition of entrepreneurship but also to the multiplicity of its research trends, embedded in a variety of scientific disciplines. These issues deepen in line with a growing awareness of the diversity of entrepreneurship forms, resulting from such aspects as its relationship with 
business, organization methods, effects of entrepreneurial activity, ownership of capital, phases of entrepreneurial activity or personal characteristics of the entrepreneur. Confronting the mainstream research themes with the forms of entrepreneurship shows that in almost every case the form of entrepreneurship should be taken into account. There are three possibilities to deal with this problem:

- conduct the research as usual, with paying attention to the form of entrepreneurship when formulating the conclusions;

- selecting the research samples with regard to the form of entrepreneurship;

- using qualitative methods.

The first option seems to be the easiest one; it allows using quantitative methods; however, the final conclusions may not be precise if the sample was random in terms of the form of entrepreneurship.

Sampling research with regard to the form of entrepreneurship seems to be unrealistic, bearing in mind the problems with conducting researches among small firms. Even if one relies only on one form of entrepreneurship, it would still mean high complexity. One can also rely on a small sample with the focus on one form of entrepreneurship - which is very often the case in social or family business research. This solution would not offer an opportunity to compare the different aspects of entrepreneurship between representatives of different forms of entrepreneurship.

The other solution is to include the forms of entrepreneurship in the selection and carry out research on a small scale. This allows for using qualitative research, whose popularity in management science in the last period increases (Kostera, 2015), although it is still not fully accepted in the mainstream research (Neergaard and Ulhøi, 2007). The drawback of this option is the limited possibility to apply the results to the entire population of entrepreneurs. Additionally, this may mean limited opportunities to publish research results, as qualitative methods are reluctantly accepted by editors of scientific journals, because there are not many specialists that can do reliable reviews of submitted papers $^{5}$. Personally the author favours the last solution, with full understanding of the limitations of the qualitative research.
The observations and conclusions are based on literature but also on author's own experience - they are polemical and contribute to the discussion on the future of research on entrepreneurship. The presented material deserves a much wider development, of which the author is aware; however, it should be treated as a platform for further discussion.

\section{Przypisy}

1 This fact has been proven by D. Ray, who investigated the literature reports entrepreneurs' propensity to take risk (Ray, 1993). It appeared that the most frequently invoked research was carried out on a group of 40 students, i.e. potential entrepreneurs in the best case.

2 The overview of definitions, for example in: (Cunnigham, Lischeron, 1991, Fillion, 1998, Landstrom, 2005, Staniewski 2016, pp. 11-13).

3 According to the long-held consensus, they include i.a.: Journal of Business Venturing, Small Business Economics, Entrepreneurship: Theory \& Practice, Journal of Small Business Management, as well as Entrepreneurship and Regional Development.

4 A more general term is habitual entrepreneurship (Spivack, McKelvie and Haynie, 2014), which includes portfolio entrepreneurship, meaning running more than one company at the same time, and serial entrepreneurship, i.e. running multiple businesses in sequence (Parker, 2014).

5 This statement is based on the discussion during the seminar: Progressing in Academic Peer Reviewing - The Good, The Bad And The Ugly, organized by EISAM, during the RENT XIX Conference in Zagreb, in 2015.

\section{References}

Aageson, T. (2008). Cultural entrepreneurs: Producing cultural value and wealth. In: H.K. Anheier and Y.R. Isar, Cultures and globalization: The cultural economy (pp. 92-108). SAGE Publications Ltd.

Ajzen, I. and Fishbein, M. (1975). Belief, attitude, intention and behavior. An introduction to theory and research. Addison-Wesley.

Audretsch, D. (2012). Entrepreneurship research. Management Decision, 755-764. Retrieved from: http://dx.doi.org/10.1108/00251741211227384.

Bandura, A. (1986). Social foundations of thought and action: A social cognitive theory. Englewood Cliffs, NY: Prentice Hall.

Barrego, H. (1989). The entrepreneur in microeconomic theory: Disappearance and explanation. London: Routledge. 
Bates, T. (2011). Minority entrepreneurship. Foundations and Trends in Entrepreneurship, 7(3-4).

Baumol, W.J. (1968). Entrepreneurship in economic theory. American Economic Review, 58(2), 64-71.

Bianchi, M. and Henrekson, M. (2005). Is neoclassical economics still entrepreneurless? Kyklos, July, 353-377.

Boeker, W. (1989). Strategic change: The effects of founding and history. Academy of Management Journal, 32(3), 489-515.

Brockhouse, R.H. and Horwitz, P.S. (1986). The psychology of the entrepreneur. In: D.L. Sexton and T.W. Smilor, The art and science of entrepreneurship (pp. 25-60). Ballinger Publishing Company.

Buzza, J. (2016). United States Association for Small Business and Entrepreneurship. Conference proceedings: CV1-CV29. Boca Raton: United States Association for Small Business and Entrepreneurship.

Carraher, S. and Paridon, T. (2008/2009). Entrepreneurship journal ranking across the discipline. Journal of Small Business Strategy, Fall/Winter, 19(2), 89-99.

Carree, M.A. and Thurik, R. (2003). The impact of entrepreneurship on economic growth. In: Z. Acs and D. Audretsch, Handbook of entrepreneurship research (pp. 437-471). Springer.

Catholic Church and John, P. (1991). Centesimus annus: Encyclical letter addressed by the Supreme Pontiff John Paul II to his venerable brothers in the episcopate, the priests and deacons, families of men and women religious, all the Christian faithful and to all men and women of good will on the hundredth anniversary of Rerum novarum (32 and 34).

Chatterjee, N. and Das, N. (2015). Key psychological factors as predictors of entrepreneurial success: A conceptual framework. Academy of Entrepreneurship Journal, 102-114.

Chell, E. (1985). The entrepreneurial personality: A few ghosts laid to rest? International Small Business Journal, Spring, 3(3), 43-54.

Chell, E. (1996). The social construction of the "entrepreneurial personality". Materials from: X RENT, November. Brussels.

Churchill, C. and Lewis, V. (1983). The five stages of small business growth. Harvard Business Review $30-50$.

Cooper, A. and Gimeno-Gascón, F. (1992). Entrepreneurs, processes of founding, and new-firm performance. In: D.K. Sexton (ed.), The state of the art of entrepreneurship (pp. 301-340). Boston: PWS-Kent Publishing Company.

Davidsson, P. (2003). The domain of entrepreneurship reserach: Some suggestions. In: J. Katz and D. Shepherd (eds.), Advances in entrepreneurship, firm emergence and growth (vol. 6). Greenwich: CT: JAI Press.

Davidsson, P. (2005). Researching entrepreneurship. New York: Springer.

Davidsson, P. (2008). The entrepreneurship research challenge. In: P. Davidsson, The entrepreneurship research challenge. Edwar Elgard.

Davidsson, P. (2009). The entrepreneurship research challenge. Edward Elgar Publishing.

Davidsson, P. and Wiklund, J. (2001). Levels of analysis in entrepreneurship research: Current research practice and suggestions for the future. Entrepreneurship Theory and Practice, Summer, 81-99.

Donna, K., Singer, S. and Herringron, M. (2016). Global Report, 2015-2016. Global Entrepreneurship Monitor.

Filion, L.J. (1998). Entrepreneurship: entrepreneurs and small business owner-manager. In: P.A. Julien (ed.), The state of the art in small business and entrepreneurship (pp. 117-149). United Kingdom: Ashgate.

Folta, T.B., Delmar, F. and Wennberg, K. (2010). Hybrid entrepreneurship (IFN Working Paper No. 825).

Fried, V. (2003). Defining a forum for entrepreneurship scholars. Journal of Business Venturing, 18(1).

Gartner, W. (1988). "Who is an entrepreneur?" is the wrong question. American Journal of Small Business, 12(4), 11-32.

Gartner, W. (2001). Is there an elephant in entrepreneurship? Blind assumptions in theory development. Entrepreneurship Theory and Practice, Summer, 25(4), 27-40.

Global Entrepreneurship Monitor Association. (2014). Global entrepreneurship monitor. Retrieved from: http://www.gemconsortium.org/wiki/1149 (14.08.2016).

Gruszecki, T. (2002). Wspótczesne teorie przedsiębiorstwa. Warszawa: Wydawnictwo Naukowe PWN

Halabisky, D. (2012). Entrepreneurial activities in Europe: Senior entrepreneurship (OECD Employment Policy Papers No. 2). OECD Publishing. http://dx.doi.org/10.1787/5jxrcml7lhxq-en.

Hebert, R.F. and Link, A.N. (1989). In search of the meaning of entrepreneurship. Small Business Economics, 1(1).

Henrekson M. (2007). Entrepreneurship and institutions (IFN Working Paper No. 707). Retrieved from: HYPERLINK "http://papers.ssrn.com/sol3/ papers.cfm?abstract_id=1006253" http://papers. ssrn.com/sol3/papers.cfm?abstract id $=1006253$ (15.08.2016).

Hughes, K.D., Jennings, J.E., Brush, C., Carter, S. and Welter, F. (2012). Extending women's entrepre- 
neurship research in new directions. Entrepreneurship Theory and Practice, 36(3), 429-442.

Hutchinson, T. (1966). A review of economic doctrines, 1870-1929. London: Oxford University Press.

Jennings, J.E. and Brush, C.G. (2013). Research on women entrepreneurs: Challenges to (and from) the broader entrepreneurship literature? The Academy of Management Annals, 661-713.

Johansson, D. (2004). Economics without entrepreneurship or institutions: A vocabulary analysis of graduate textbooks. Econ Journal Watch, 1(3), 515-538.

Jones, G. and Wadhwani, D. (2006). Entrepreneurship and business history: Renewing the research agenda (Working paper).

Kelley, D., Singer, S. and Herrington, M. (2016). Global entrepreneruship monitor 2015/2016. GERA.

Kilby, P. (1971). Hunting the Heffalump. Entrepreneurship and Economic Development, 1-40.

Kirby, D. (2003). Entreprenuership. Bershire: McFraw-Hill Education.

Kirchhoff, B. (1991). Entrepreneurship's contribution to economics. Entrepreneurship Theory and Practice, Winter, 93-112.

Kostera, M. (ed.) (2015). Metody badawcze w zarzadzaniu humanistycznym. Warszawa: Wydawnictwo Akademickie Sedno.

Kostera, M. and Śliwa, M. (2012). Zarządzanie w XXI wieku. Wolters Kluwer.

Krueger, N. (2003). The cognitive psychology of entrepreneurship. In: Z. Acs and D. Audretsch (eds.), Handbook of entrepreneurship research (pp. 105-140). London: Kluwer Law International.

Krueger, N.F., Reilly, M. and Carsrud, A. (2000) Competing models of entrepreneurial intentions. eneurial intentions. Journal of Business Venturing, 15(5/6), 411-432.

Kurczewska, A. (2013). Przedsiębiorczość. Warszawa: Polskie Wydawnictwo Ekonomiczne.

Kwiatkowski, S. (2000). Przedsiębiorczość intelektualna. Warszawa: Wydawnictwo Akademii Leona Koźmińskiego.

Landstrom, H. (2005). Pioneers in entreprneurship and small business research. Springer.

Landstrom, H. and Lohrke, F. (2010). Historical foundations of entrepreneurship research. Cheltenham, UK/Northampton, MA, USA: Edward Elgar Publishing Limited.

Low, M. (2011). The adolescence of entrepreneurship research: Specification of purpose. Entrepreneurship Theory and Practice, Summer, 17-25.

Low, M and MacMillan, I. (1988). Entrepreneurship: Past research and future challenges. Journal of Management, 35, 139-161. de Massis, A., Sharma P., Chua J. and Chrismas J. (2012). Family business studies: An annotated bibliography. Cheltenham, UK/Northampton, MA, USA: Edward Elgar Publishing Limited.

McClelland, D. (1961). The achieving society. Princeton, NJ: van Nostrand.

McClelland, D. (1987). Human motivation. Cambridge: Cambridge Universtity Press.

McClelland, D. (1965). Toward a theory of motive acquisition. American Psychologist, 20(5), 321-333.

Moczydłowska, J. (2013). Nauki o przedsiębiorczości. O potrzebie interdyscyplinarnej płaszczyzny badawczej. In: J.E. Wasilczuk (ed.), Przedsiębiorczość w ośmiu odstonach (pp. 9-17). Gdańsk: Politechnika Gdańska.

Neergaard, H., Shaw, E. and Carter, S. (2005). The impact of gender, social capital and networks on business ownership: A research agenda. International Journal of Entrepreneurial Behavior \& Research, 338-357.

Neergaard, H., Ulhøi, J. (2007). Handbook of qualitative research methods in entrepreneurship. Cheltenham, UK/Northampton, MA, USA: Edward Elgar Publishing Limited.

Penrose, E. (1959). The theory of the growth of the firm. New York: Oxford University Press.

Petrova, K. (2011) Part-time entrepreneurship, learning and ability. Journal of Management Policy and Practice, 12(1), 64-75.

Piecuch, T. (2014). Przedsiębiorczość, podstawy teoretyczne. Warszawa: C.H. Beck.

Pinchot, G. (1984). Who is the intrapreneur? In Intrapreneuring: Why you don't have to leave the corporation to become an entrepreneur. New York: Harper \& Row.

Rauch, A. and Frese, M. (2000). Psychological approaches to entrepreneurial success. A general model and an overview of findings. In: C.L. Cooper and I.T. Robertson (eds.), International review of industrial and organizational psychology (pp. 101142). Chichester: Wiley.

Ray, D. (1993). Understanding the entrepreneur: Entrepreneurial attributes, experience and skills. Entrepreneurship and Regional Development, 5(4), 345-358.

Redlich, F. (1949). The origin of the concepts of "entrepreneur" and "creative entrepreneur". Explorations in Entrepreneurial History, 1(2), 1-7.

Rerup, C. (2005). Learning from past experience: Footnotes on mindfulness and habitual entrepreneurship. Scandinavian Journal of Management, 451-472.

Richert-Kaźmierska, A. and Wasilczuk, J.E. (2014). Zatrudnienie czy samozatrudnienie - dylematy wspierania aktywności zawodowej osób starszych. 
Studia Ekonomiczne, 167, 148-155. Wydawnictwo Uniwersytetu Ekonomicznego w Katowicach.

Ries, E. (2010). Is entrerpreneurship a management science. Retrieved from: https://hbr.org/2010/01/is-entrepreneurship-a-management (30.08.2016).

Rosa, P. and Scott, M. (1999). The prevalence of multiple owners and directors in the SME sector: Implications for our understanding of start-up and growth. Entrepreneurship and Regional Development, 11, 21-37.

Seymour, R. (ed.). (2012). Handbook of research methods on social entrepreneurship. Cheltenham, UK/Northampton, MA, USA: Edward Elgar Publishing Limited.

Shapero, A. and Sokol, L. (1982). Social dimensions of entrepreneurship. In: C.A. Kent, D.L. Sexton and K.H. Vesper, The encyclopedia of entrepreneurship (pp. 72-90). Englewood: Prentice-Hall.

Shaver, K. and Scott, L. (1991). Person, process, choice: The psychology of new venture creation. Entrepreneurship Theory and Practice, Winter, 23-45.

Silva, O. (2006). The Jack-of-all-trades entrepreneur: Innate talent or acquired skill? (London School of Economics and IZA Bonn. Discussion Paper No. 2264).

Staniewski, M. (2016). Organizational and psychological predictors of entrepreneurial success. Saarbrucken: LAB Lambert Academic Publication.

Storey, D. (1994). Understanding the small business sector. Sussex.

Terelak, J. (1999). Psychologia menedżera. Warszawa: Difin.
The American Presidency Project. (1985). President Reagan's remarks to the students and faculty at St. John's University in New York, New York on March 28, 1985. Retrieved from: http://www.presidency.ucsb.edu/ws/?pid=38403 (28.08.2016).

The Economist. (2009). Retrieved from: http://www. economist.com/node/13565718 (10.08.2016).

van Praag, C.D. (1999). Some classic views on entrepreneurship. De Economist, 147(3), 147-311.

Venkataraman, S. (1997). The distinctive domain of entrepreneurship research. Advances in Entrepreneurship, Firm Emergence and Growth, 119-138.

Wasilczuk, J.E. (2005). Wzrost matych i średnich przedsiębiorstw - aspekty teoretyczne i badania empiryczne. Gdańsk: Politechnika Gdańska.

Wasilczuk, J.E. (2009). Investigate or not the entrepreneurship - problem with methodology. In: Wasilczuk, J.E. (ed.), What do we know (and would like to know) about entrepreneurship in Poland (pp. 8-17). Gdańsk: Politechnika Gdańska.

Welsh, J. and White, J. (1981). A small business is not a little big business. Harvard Business Review.

Welter, F. (2001). Contextualizing entrepreneurship-conceptual challenges and ways forward. Entrepreneurship Theory and Practice, 165-184.

Westhead, P. and Wright, M. (1998). Novice, portfolio, and serial founders: Are they different? Journal of Business Venturing, 173-204.

Wood, G.J., Davidson, M.J. and Fielden, S.L. (2012). Minorities in entrepreneurship: An international review. Edward Elgar Publishing.

Zahra, S. and Dess, G.G. (2001). Entrepreneurship as a field of research: Encouraging dialogue and debate. Academy of Management Review, 8-10. 